\title{
Traumatic internal carotid artery dissection associated with playing soccer: a case report
}

\author{
Futbol oynamaya bağlı travmatik arteria karotis interna diseksiyonu: Olgu sunumu
}

\author{
Nida TAŞCILAR, ${ }^{1}$ Banu ÖZEN, ${ }^{1}$ Mustafa AÇIKGÖZ, ${ }^{1}$ Süreyya EKEM, ${ }^{1}$ Esra ACIMAN, ${ }^{1}$ Sanser GÜL ${ }^{2}$
}

Soccer, one of the most popular sports worldwide among young men, can result in a wide range of orthopedic injuries. Although vascular injuries such as dissection occur rarely, they can cause significant mortality if left undiagnosed. We report herein a 31-year-old male who suffered a large middle cerebral artery infarction due to traumatic internal carotid artery dissection after a ball struck his head and neck. He recovered with mild neurologic deficit after decompressive surgery.

Key Words: Dissection; internal carotid artery; soccer.
Tüm dünyada genç erkekler arasında en sevilen sporlardan biri olan futbol, pek çok ortopedik yaralanmalara yol açabilir. Diseksiyon gibi vasküler yaralanmalar nadir görülmelerine rağmen, tanı konulmadığında ölüme sebebiyet verebilir. Bu yazıda, başına ve boynuna futbol topu çarptıktan sonra travmatik internal karotid arter diseksiyonu oluşarak geniş orta serebral arter infarktı gelişen 31 yaşındaki erkek hasta sunuldu. Hasta dekompresif cerrahi sonrası hafif nörolojik hasarla düzeldi.

Anahtar Sözcükler: Diseksiyon, internal karotid arter; futbol.
Central nervous system (CNS) injury due to severe head trauma can occur in many sports activities. ${ }^{[1]}$ CNS injury associated with football or soccer has been reported in the form of intracranial hemorrhage. [2] Development of dissection is a very rare and uneventful finding. Despite its rarity, early diagnosis and treatment are of paramount importance in preventing complications. ${ }^{[2,3]}$ Although neurologists and vascular surgeons are familiar with this condition, general practitioners, medical staff in sports, and other athletes who may be the first to help such patients are far less acquainted with this condition.

We herein describe a patient who developed dissection due to blunt trauma while playing soccer.

\section{CASE REPORT}

A 31-year-old male was admitted to the emergency room with impaired consciousness and right-sided weakness. He routinely played amateur soccer once a week with his friends. One week before admission, his left eye had been struck by the ball. He complained of numbness in his right arm, but did not seek any medical attention. Six hours prior to admission, while playing in another match, the ball struck the left side of his neck, after which he continued playing for an additional approximately 40 minutes, but he lost consciousness before completion of the game.

The neurologic examination on admission revealed decreased consciousness, right central facial paresis, right hemiplegia, sensorimotor aphasia, and right Babinski sign. Glasgow coma scale (GCS) of 7 (eye opening to speech, verbal response none [due to sensorimotor aphasia], motor response flexing to pain), modified Rankin scale of 5, Barthel index of 0 , and National Institutes of Health (NIH) stroke scale of 11 were determined. He did not have Horner's syndrome; any systemic disease such as hypertension or metabolic or endocrine diseases (including diabetes mellitus); collagenosis; inflammation; liver, renal, cardiac, or neoplastic diseases; or migraine. He reported never smoking cigarettes or using drugs. 
A computed tomography scan of the head $(\mathrm{CTH})$ taken on admission was normal. Bilateral carotid artery Doppler sonography demonstrated a decreased flow velocity of the left carotid artery with a distorted spectrum, and no flow could be detected distally. Cranial magnetic resonance angiography (MRA) showed absent flow in the distal segments of the internal carotid artery (ICA) with a narrowed M1 segment (Fig. 1a). His second $\mathrm{CTH}$ taken 24 hours after the first showed a large left middle cerebral artery infarction with a mass effect compressing the lateral ventricle (Fig. 1b). Since the GCS worsened, decompressive surgery was performed by the Neurosurgery Department to reduce pressure (Fig. 1c). Other than mild hypertriglyceridemia, his lipid profile, lipoprotein(a), homocysteine, vitamin B12, folic acid, hemoglobin A1C levels, thyroid function tests, coagulation parameters, and echocardiography were normal. After decompressive surgery, antiaggregant therapy was initiated. He is now on acetylsalicylic acid (ASA) and dipyridamole therapy. The neurologic examination four months after the decompressive surgery revealed a mild motor aphasia and a right-sided spastic hemiparesis (3-4/5). Modified Rankin scale, Barthel index, and NIH stroke scale were 3, 80 and 5, respectively.

\section{DISCUSSION}

Numerous sporting activities, such as football, boxing, hockey, and various winter activities, are associated with CNS injuries. ${ }^{[1]}$ One such injury, ICA dissection, has been reported to occur during a variety of sports, such as scuba diving, ${ }^{[3]}$ treadmill running ${ }^{[4]}$ triathlon, ${ }^{[5]}$ springboard diving ${ }^{[6]}$ taekwondo, ${ }^{[7]}$ French boxing ${ }^{[8]}$ rugby ${ }^{[9]}$ winter activities, ${ }^{[10]}$ baseball, ${ }^{[11]}$ golf, ${ }^{[12]}$ and softball ${ }^{[13]}$ due to blunt trauma. ${ }^{[14]}$ Although soccer is one of the most popular sports among athletes, head and vascular injuries rarely occur. ${ }^{[15]}$ To date, few artery dissections have been reported in association with soccer ${ }^{[15-18]}$ To our knowledge, the present case is the first ICA dissection due to ball trauma during soccer.

Approximately $20 \%$ of strokes in patients less than 45 years of age are due to extracranial ICA or vertebral artery dissection. ${ }^{[19,20]}$ ICA dissection is one of the major causes of cerebral infarction in patients under 50 years old. ${ }^{[19]}$ Traumatic dissection occurs in nearly $1 \%$ of all patients with blunt injury mechanisms. ${ }^{[20]}$

Other than trauma, cervical artery dissection could be due to numerous risk factors, such as connective tissue disorders, hyperhomocysteinemia, recent infection, $\alpha 1$-antitrypsin deficiency, and migraine. ${ }^{[21]}$ Headache, neck pain, Horner's syndrome, lower cranial nerve palsy, and ischemic cerebrovascular disease were reported as the most common signs. ${ }^{[22,23]}$ Ischemic stroke could develop at presentation or days thereafter. ${ }^{[22,23]}$ In the present case, although ischemic symptoms had developed at the initial event, no treatment could be given to prevent complications because the patient did not seek medical attention.

Arterial dissection can cause ischemic stroke either by thromboembolus forming at the site of the injury or as a result of hemodynamic insufficiency due to severe stenosis or occlusion. Although both anticoagulation and antiplatelet agents are among the current treatment modalities, there is limited evidence as to which is preferred ${ }^{[20]}$ Our patient was treated with antiplatelet agent after decompressive surgery because of the large infarct size.

Magnetic resonance angiography (MRA) can be used in the assessment of patients with suspected dis-
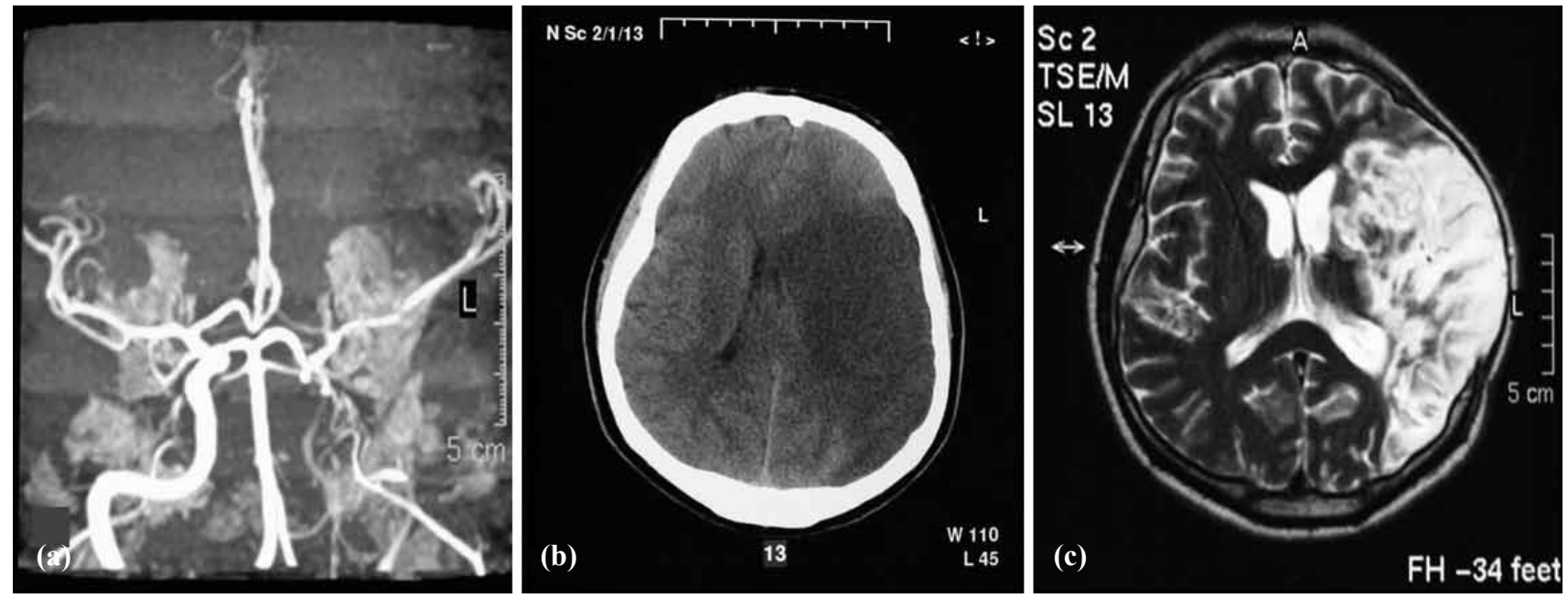

Fig. 1. (a) Cranial magnetic resonance angiogram demonstrated absent flow in the distal segments of the internal carotid artery with a narrowed M1 segment. (b) CT scan of the brain: large left middle cerebral artery infarction is seen, with a mass effect compressing the lateral ventricle. (c) MRI of the cranium after decompressive surgery. In the axial T2-weighted image, left middle cerebral artery infarction is seen. 
section of the carotid or vertebral arteries. ${ }^{[24]} \mathrm{MR}$ or $\mathrm{CT}$ angiography in dissection can demonstrate luminal narrowing, vessel irregularity, wall thickening/hematoma, pseudoaneurysm, and intimal flap. ${ }^{[24]}$ Doppler ultrasonography has also been used in the diagnosis of ICA dissection. ${ }^{[23]}$ In our case, Doppler sonography and MRA revealed ICA stenosis with narrowed distal segments.

Mortality due to trauma associated with soccer is rarely reported. In the study of McCrory et al., ${ }^{[2]} 9$ of 25 patients died of CNS injuries associated with soccer over a period of 32 years. While 8 of 9 died of intracranial hemorrhage, only 1 died of middle cerebral artery infarction. Although our patient also developed large middle cerebral artery territory infarction after the second trauma, the rapidly performed decompressive surgery was likely lifesaving in this case since the mortality rate without this procedure is around $80 \%{ }^{[25]}$

In conclusion, although carotid artery dissection associated with soccer and other sports is rare, familiarization with its neurologic symptoms (headache, neck pain, numbness, vertigo, etc.) and deficits (hypoesthesia, hemiparesis, myosis, ptosis, hemianopsia, etc.) and education of the population regarding the diagnosis can be lifesaving.

\section{REFERENCES}

1. Toth C, McNeil S, Feasby T. Central nervous system injuries in sport and recreation: a systematic review. Sports Med 2005;35:685-715.

2. McCrory PR, Berkovic SF, Cordner SM. Deaths due to brain injury among footballers in Victoria, 1968-1999. Med J Aust 2000;172:217-9.

3. Skurnik YD, Sthoeger Z. Carotid artery dissection after scuba diving. Isr Med Assoc J 2005;7:406-7.

4. Macdonald DJ, McKillop EC. Carotid artery dissection after treadmill running. Br J Sports Med 2006;40:e10.

5. Sparing R, Hesse MD, Schiefer J. Traumatic internal carotid artery dissection associated with triathlon: a rare differential diagnosis. Sportverletz Sportschaden 2005;19:211-3. [Abstract]

6. Furtner M, Werner P, Felber S, Schmidauer C. Bilateral carotid artery dissection caused by springboard diving. Clin $\mathrm{J}$ Sport Med 2006;16:76-8.

7. Pary LF, Rodnitzky RL. Traumatic internal carotid artery dissection associated with taekwondo. Neurology 2003;60:1392-3.

8. Echaniz-Laguna A, Fleury MC, Petrow P, Arnould G, Beaujeux R, Warter JM. Internal carotid artery dissection caused by a kick during French boxing. Presse Med 2001;30:683.
[Abstract]

9. Miyata M, Yamasaki S, Hirayama A, Tamaki N. Traumatic middle cerebral artery occlusion. No Shinkei Geka 1994;22:253-7. [Abstract]

10. Stampfel G. Winter sport injuries to the carotid artery. Radiologe 1983;23:426-30. [Abstract]

11. Benedict WJ, Prabhu V, Viola M, Biller J. Carotid artery pseudoaneurysm resulting from an injury to the neck by a fouled baseball. J Neurol Sci 2007;256:94-9.

12. Choi KD, Oh SJ, Yang TI, Lee TH. Golfer's stroke from internal carotid artery dissection. Arch Neurol 2008;65:1122-3.

13. Schievink WI, Atkinson JL, Bartleson JD, Whisnant JP. Traumatic internal carotid artery dissections caused by blunt softball injuries. Am J Emerg Med 1998;16:179-82.

14. Dharmasaroja P, Dharmasaroja P. Sports-related internal carotid artery dissection: pathogenesis and therapeutic point of view. Neurologist 2008;14:307-11.

15. Reess J, Pfandl S, Pfeifer T, Kornhuber HH. Traumatic occlusion of the internal carotid artery as an injury sequela of soccer. Sportverletz Sportschaden 1993;7:88-9. [Abstract]

16. Jörger G, Thielemann F. Traumatic vertebral artery dissection in an 8 year old boy. Unfallchirurg 2004;107:803-6. [Abstract]

17. Motohashi O, Kameyama M, Kon H, Fujimura M, Onuma T. A case of vertebral artery occlusion following heading play in soccer. No Shinkei Geka 2003;31:431-4. [Abstract]

18. Weinstein SM, Cantu RC. Cerebral stroke in a semipro football player: a case report. Med Sci Sports Exerc 1991;23:1119-21.

19. Mokri B, Sundt TM Jr, Houser OW, Piepgras DG. Spontaneous dissection of the cervical internal carotid artery. Ann Neurol 1986;19:126-38.

20. Redekop GJ. Extracranial carotid and vertebral artery dissection: a review. Can J Neurol Sci 2008;35:146-52.

21. Rubinstein SM, Peerdeman SM, van Tulder MW, Riphagen I, Haldeman S. A systematic review of the risk factors for cervical artery dissection. Stroke 2005;36:1575-80.

22. Schievink WI. Spontaneous dissection of the carotid and vertebral arteries. N Engl J Med. 2001;344:898-906

23. Treiman GS, Treiman RL, Foran RF, Levin PM, Cohen JL, Wagner WH, et al. Spontaneous dissection of the internal carotid artery: a nineteen-year clinical experience. J Vasc Surg 1996;24:597-607.

24. Vertinsky AT, Schwartz NE, Fischbein NJ, Rosenberg J, Albers GW, Zaharchuk G. Comparison of multidetector CT angiography and MR imaging of cervical artery dissection. AJNR Am J Neuroradiol 2008;29:1753-60.

25. Vahedi K, Hofmeijer J, Juettler E, Vicaut E, George B, Algra A, et al. Early decompressive surgery in malignant infarction of the middle cerebral artery: a pooled analysis of three randomised controlled trials. Lancet Neurol 2007;6:215-22. 